\title{
Što je to postimperijalna suverenost? Uz Nomos zemlje - Carl Schmitt i kritičko čitanje Hanne Arendt
}

\author{
ŽARKO PAIĆ \\ Tekstilno-tehnološki fakultet, Sveučilište u Zagrebu
}

\begin{abstract}
Sažetak
Autor u članku analizira Schmittov spis Nomos zemlje postavljajući pitanje na koji se način nakon epohe nacije-države i kraha europskoga imperijalizma, što je bila i ishodišna postavka Hanne Arendt u njezinim Izvorima totalitarizma, uspostavljaju uvjeti mogućnosti političkoga djelovanja, budući da to djelovanje više nema za svoj egzistencijalni prostor ideju ukorijenjenosti u naciju kao državu s mehanizmima zaštite suverenosti s pomoću zakonodavne, izvršne i sudske vlasti zapisane u ustavu. Moć nije pritom tek državno-društvena logika upravljanja fiksnim prostorom i ograničenim teritorijem nacije-države, kako je to bilo uobičajeno od 18. stoljeća u Europi do kraja I. svjetskoga rata. Sam je Schmitt u drugome razdoblju njegova filozofijsko-pravnoga mišljenja, formalno i sadržajno nakon kraja II. svjetskoga rata, političko i politiku sagledao kao univerzalnu geopolitiku "velikoga prostora" (Großraum). Egzistencijalno-decizionistički obrat pokazuje se odlučujućim razlogom zbog čega se Schmittov pojam političkoga ne može proglasiti opravdanjem bilo kakve diktature ili totalitarizma. Odluka počiva na praznom središtu slobode, a ne moći. Nomos zemlje u postnacionalnoj konstelaciji za Schmitta na taj način postaje pitanje poretka i uprostorenja u osvajanju i prisvajanju zemlje u stalnim ratovima i sukobima s Drugim, jer je čovjek sve drugo negoli po prirodi dobar. Kritika ove pozicije u marginalijama Hanne Arendt uz Schmittovu knjigu Nomos zemlje otvara mogućnost rasprave o granicama neoimperijalizma i nove pravno-političke konstitucije svijeta nakon II. svjetskoga rata. Autor smatra da je rezultat ove aporetične i paradoksalne situacije u 21. stoljeću upravo u tzv. postimperijalnoj suverenosti kao nastavku Schmittove postavke o izvanrednom stanju na globalno-planetarnoj razini. Političko otuda prethodi politici kao što novi nomos zemlje zahtijeva obrat u razumijevanju odnosa slobode i moći.
\end{abstract}

Ključne riječi: postimperijalna suverenost, Schmitt, Arendt, Nomos zemlje, politička teologija, neoimperijalizam 


\section{Uvod}

Spis Carla Schmitta Nomos zemlje predstavlja jedan od najznačajnijih i ujedno najspornijih pristupa političkoga mišljenja u 20. stoljeću kraju epohe nacije-države. Nakon kraha europskoga imperijalizma, o čemu je govorila i Hannah Arendt u Izvorima totalitarizma, pojavljuje se otvoreno područje za nove mogućnosti političkoga djelovanja s onu stranu tradicionalnih pojmova i kategorija kao što su to nacionalnost, država, suverenost u kontekstu zakonodavne, izvršne i sudske vlasti zapisane u ustavu. Schmitt je nakon kraja II. svjetskoga rata dospio do postavke o kraju ere državnosti, a to znači da je pojmove političkoga i politike pokušao sagledati u horizontu univerzalne geopolitike "velikoga prostora" (Großraum). Egzistencijalnodecizionistički obrat pokazuje se odlučujućim razlogom zbog čega se Schmittov pojam političkoga ne može proglasiti opravdanjem bilo kakve diktature ili totalitarizma. Odluka počiva na praznom središtu slobode, a ne moći. Nomos zemlje u postnacionalnoj konstelaciji za Schmitta na taj način postaje pitanje poretka i uprostorenja u osvajanju i prisvajanju zemlje u stalnim ratovima i sukobima s Drugim, jer je čovjek sve drugo negoli po prirodi dobar. Kritika ove pozicije u marginalijama Hanne Arendt uz Schmittovu knjigu Nomos zemlje otvara mogućnost rasprave o granicama neoimperijalizma i nove pravno-političke konstitucije svijeta nakon II. svjetskoga rata. U ovom članku će se nastojati pokazati da je rezultat ove aporetične i paradoksalne situacije u 21. stoljeću upravo u postimperijalnoj suverenosti kao nastavku Schmittove postavke o izvanrednom stanju na globalno-planetarnoj razini. Političko otuda prethodi politici kao što novi nomos zemlje zahtijeva obrat $\mathrm{u}$ razumijevanju odnosa slobode i moći.

Političko i politika ne mogu se nikad svesti na zajednički nazivnik, šmitovski rečeno, logike neutraliziranja i depolitiziranja. Sjetimo se da je u znamenitome govoru iz Barcelone 1927. godine naslovljenom "Doba neutraliziranja i depolitiziranja" Carl Schmitt svjetsku povijest kao povijest sekulariziranja odredio upravo kroz tri silazne putanje skidanja Boga s prijestolja filozofije i teologije. To su, za njega, prijelazi od "teologijskoga do metafizičkoga, i otuda do humanitarno-moralnoga i naposljetku ekonomijskoga" (Schmitt, 1932, str. 67; Vesting, 1992). Već je odatle izvjesno da smo suočeni s razumijevanjem onoga što pripada kritici filozofije povijesti kao filozofije politike, prava i države, kad je riječ o pokušaju da se misli ono što je različitim strategijama redukcije postalo samorazumljivo bez dubljeg odnosa s izvornom tradicijom mišljenja političkoga i politike. Schmitt je u govoru u Barceloni, a isto tako i u svojoj Političkoj teologiji dospio do naizgled sveopće primjenjivoga rješenja u dijagnozi suvremenoga doba. Iskazivao ga je sinonimno kao doba sekularizacije, neutraliziranja, depolitiziranja, tehničkoga ekonomiziranja. Najznačajnija njegova definicija ovoga procesa univerzalnog prevođenja svetoga u svjetovno sa svim popratnim posljedicama već je postala krilaticom političkoga mišljenja uopće. 
Svi pregnantni pojmovi moderne teorije države sekularizirani su teološki pojmovi. Ne samo po svom povijesnom razvoju, jer su iz teologije preneseni na nauk o državi, tako što je, primjerice, svemoćni Bog postao omnipotentnim zakonodavcem, nego i u svojoj sistematičkoj strukturi, čija je spoznaja nužna za sociološko razmatranje tih pojmova. Iznimno stanje za pravnu znanost ima značenje analogno čudu u teologiji. Tek sa sviješću o takvom analognom položaju može se prepoznati razvojni put kojim su državnofilozofske ideje krenule tijekom posljednjih stoljeća. Jer, ideja moderne pravne države etablira se s deizmom, s jednom teologijom i metafizikom, koja čudo izopćava iz svijeta, a u pojmu čuda sadržano probijanje prirodnih zakona, koje neposrednim upletanjem uspostavlja iznimku, odbacuje jednako kao i neposredno upletanje suverena u važeći pravni poredak. (Schmitt, 2019a, str. 41).

Što nam to sve govori u 21. stoljeću ako ne da je shvaćanje političkoga i politike ono koje prethodi svakome mogućem redukcionizmu? U filozofijskome mišljenju suvremenosti ponajprije ga je razobličio Heidegger u Bitku i vremenu iz 1927. godine ustvrdivši da pitanje o smislu bitka u njegovoj izvornoj vremenosti ne doseže nikakav moderni antropologizam, biologizam i psihologizam (Heidegger, 2018). Čovjek, život i duša ne mogu biti uspostavljeni znanstveno kao predmetnost predmeta koja od novoga vijeka otpočinje s uzorom u matematici i fizici kao temeljnim prirodnim znanostima. Isto je učinio i Schmitt 1920-ih i početkom 1930-ih godina u području političkoga djelovanja. Ono ne može biti, pak, svedeno na etičko-moralne kategoričke imperative, niti na derivate znanosti, kulture, ekonomije i tehnike. Ono što povezuje Heideggera i Schmitta, unatoč bitnim razlikama, jest uvid da moderna tehnika dovodi u pitanje egzistencijalnu slobodu čovjeka, i to ne samo u njegovim duhovno-duševnim očitovanjima u umjetnosti već i u području koje pripada bezuvjetnoj nesvodivosti političkoga i politike (Paić, 2017, str. 219-266). Razlog ovome povratku tragičnoga kao estetskoga i mitsko-religioznoga u razumijevanje političkoga djelovanja jest pokušaj da se mišljenju onoga što nije ni sredstvo ni krajnja svrha ljudske egzistencije, a bez toga nema smislene povijesti uopće, podari istinsko dostojanstvo nakon što je izgubilo ontologijski karakter kontingentnoga događaja, ili šmitovskim jezikom rečeno - čuda. No, ono što je i za Schmitta i sve postmoderne "decizioniste" u okviru političkoga mišljenja događaja na tragu Badioua ili Agambena svojevrsni misterij u doba bez tajne jest pitanje izvora ovoga čuda koje prethodi razdoblju posvemašnjeg tehničkoga redukcionizma. Ako je, u krajnjem, i za Schmitta i za Foucaulta i Deleuzea posve neporecivo da je ključ razrješenja ove zagonetke u suvremenom razdoblju vladavine neoliberalne aksiomatike kapitalizma ništa drugo negoli metafizičko utemeljenje Moći, jer ona odlučuje o karakteru političkoga djelovanja, a ne dobre namjere i normativizam utopijskih ciljeva, onda je temeljni razlog prodora iracionalizma, kontingencije, estetskoga viška zbilje u 
težnji za dohvaćanjem ove čudovišne pokretačke snage oblikovanja država i carstava uopće (Critchley, 2012, str. 103-108; Žižek, 1999).

Odmah valja raščistiti s eventualnim prigovorom da sadašnjem poretku vladavine neoliberalnog informacijskoga kapitalizma svaki mogući kritički ton tzv. alternative znači i pad u mistifikaciju iskona, autentičnosti nekog "novog" političkoga subjekta izvan redukcije na rad i klasu, kao što je, uostalom, baš Carl Schmitt pronalazio cilj svoje političke ontologije u odbacivanju ideologija liberalizma, marksizma i anarhizma. Ovdje nije posrijedi puki povratak Schmittu kao teoretičaru decizionizma u smislu neproračunljiva i kontingentnoga događaja koji, da paradoks bude potpun a aporija nerješiva, prethodi onome što doslovno "izluđuje" normativizam i pozitivizam tzv. državnoga prava s tradicijom njemačke škole od Kelsena do Jelineka i drugih. Razlog što je Schmitt kao moderni nastavljač Hobbesa u shvaćanju države, suverenosti, metafizike, prirodnoga prava, diktature i demokracije, političke teologije, zacijelo paradigmatski mislilac političkoga i politike u čistoći ovih pojmova ne leži ni u kakvoj desnoj ili lijevoj uporabi njegovih stavova, primjerice, u kritici američkoga imperijalizma i hegemonije ili, pak, uvida o kraju države u tradicionalnome shvaćanju njezine uloge kao nositelja suverenosti (Wollin, 1992; McCormick, 1997). ${ }^{1}$ Problem s kojim se mi u suvremenosti vladavine globalno-planetarne tehnosfere ${ }^{2}$ i nastanka nove forme postimperijalne suverenosti susrećemo nadilazi ovaj ideologijski uski horizont prihvaćanja ili odbijanja njegovih stavova. Međutim, za razliku od takvih pristupa ovdje nastojimo u Schmittovu političkome mišljenju pronaći ono bitno što ga čini našim mjerodavnim suvremenikom isto kao i Heideggera. Utoliko više što se u ovom razmatranju kao i u drugim prethodnim pokušajima moje stajalište kreće u okviru neutraliziranja upravo svake moguće re-ideologizacije. Nije mi cilj rehabilitirati Schmitta za potrebe neke lijeve postpolitike, a

${ }^{1}$ Rodin ističe: "S pojmom odluke ex nihilo, odlukom posredstvom izbora te pojmom izvanrednog stanja Schmitt pokazuje da između prava i politike postoji neprevladiva asimetrija tih moći, ili medija koje nije moguće ujediniti pojmom državnog suvereniteta. Schmitt je među prvima uvidio da je u razvijenim demokracijama došlo do raspada jedinstva suvereniteta i državnosti budući da narod nije singularia tantum, već mnogoglava i nepredvidljiva neman. Stabilnost ili suverenost države nije u njoj samoj, već u onim političkim snagama koje kontroliraju izvanredno stanje. Posljednja suverena instancija nije ni Bog ni narod, nego oni slučajni subjekti koji u kritičnom trenutku izvanrednog stanja raspolažu najvećom moći. Izvanredno stanje nema u Schmitta ni ontološko, ni mitološko, nego semantičko značenje" (Rodin, 2012, str. 263).

${ }^{2}$ Pojam tehnosfere kako sam ga teorijski artikulirao u petoknjižju Tehnosfera pretpostavlja vladavinu tehno-geneze kao sustava upravljanja svijetom polazeći od četvorstva informacije povratne sprege - kontrole - komunikacije. Tehnosfera uvodi u razumijevanje suvremenoga globalno-planetarnoga okvira djelovanja mogućnost, zbilju i nužnost preobrazbe života u posthumano stanje, u kojem kodovi prethode nastanku sklopa umjetnoga života. Poredak počiva na umrežavanju informacija i interakciji sustava i okoline u svim aspektima života od društva, politike, kulture (Paić, 2018, 2019). 
ponajmanje da bi ga se ponovno upreglo u mislioca podobnog za ekstremna stajališta metapolitičke desnice u 21. stoljeću. Čak i ako su postavke inih zagovornika radikalne kritike Schmitta i Heideggera u prilozima Wollina i drugih u mnogo čemu neoborive, valja stvar svesti na pravu mjeru moguće kritike njegovih polazišta i ishodišta te konzekvencija koje proizlaze iz dubinskoga čitanja Nomosa zemlje. Za tako nešto potrebno je unijeti u raspravu kritičko čitanje kakvo je poduzela upravo Hannah Arendt. Zašto? Iz jednostavnog razloga što je to važno svjedočanstvo traganja za drukčijim razjašnjenjem istoga problema kao što je to odnos političkoga i politike u razdoblju postimperijalne suverenosti.

Kao i u slučaju Foucaulta i Deleuzea, čini se da je bez objašnjenja dispozitiva moći koji vlada u doba umreženih struktura korporativnoga kapitalizma nemoguće misliti bit političkoga i politike. Moć nije pritom tek državno-društvena logika upravljanja fiksnim prostorom i ograničenim teritorijem nacije-države, kako je to bilo uobičajeno od 18. stoljeća u Europi do kraja I. svjetskoga rata. Sam Schmitt je u drugome razdoblju svojega filozofijsko-pravnoga mišljenja, formalno i sadržajno nakon kraja II. svjetskoga rata, političko i politiku sagledao kao Großraum $^{3}$ - univerzalnu geopolitiku "velikoga prostora" (McCormick, 1997).

Odrediti geopolitiku polazeći od postavke o raspadu poretka nacionalnih država, a taj proces trajao je od 18. stoljeća do 1945. godine, znači preusmjeriti razumijevanje političkoga i politike polazeći od drukčijeg izvođenja pojma Moći. Ono što je, međutim, taj pojam za sociologijsko određenje kakvo u vidu ima Michel Foucault, pa čak i Gilles Deleuze, s onu stranu granica tradicionalnoga pojma društva u razlici spram države, a to su izrazi poput disciplinarnoga, nadzornoga i društva kontrole, ne može se pripisati Schmittovu shvaćanju Moći. Dok, naime, Foucault i Deleuze kao i čitava struja postfundacionalista nastoje simbolički i zbiljski očuvati ili obraniti društvo od totalne tehnološko-ekonomske neoliberalne redukcije na strukture i funkcije korporativnoga pogona u poretku globalizma kao svjetskoga tržišta, u slučaju Schmitta posrijedi je pokušaj očuvanja biti onog političkoga i politike bez temelja ideje suverenosti države. Društvo protiv države samo bi po analogiji bilo ovdje ono što se pokazuje u sporu između, uvjetno rečeno, ideja Foucaulta i Deleuzea s jedne strane te Schmittovih postavki s druge strane. Zajednič-

${ }^{3}$ Izraz koji je prvi upotrijebio Schmitt 1930-1940-ih godina danas se uobičajeno poistovjećuje s pojmovima globalizacije i globalizma. No, isto tako valja otkloniti i posvemašnju blizinu s nacističkim pojmom Lebensrauma. U samom je pojmu na djelu sveza političke geografije i geopolitike u svjetlu proširenog shvaćanja prostora i prostornosti s obzirom na temeljnu postavku o kraju nacija-država u razdoblju koje karakterizira vladavina moderne tehnologije i uspostavljanje novih imperijalnih tvorevina. Ono što uvjetuje i određuje logiku razdiobe i upravljanja takvim prostorom razvio je, kako je poznato, u djelu Nomos zemlje u međunarodnom pravu Ius Publicum Europaeum iz 1950. godine (Schmitt, 1974). 
ko je obama stajalištima da ne mogu bezuvjetno pristati na pasivno sudjelovanje $u$ neoimperijalnome poretku vladavine svijetom kojim više ne vladaju političko-kulturalne ideje poput slobode, jednakosti, pravednosti i solidarnosti, već oligarhijska mreža kapitala kao upravljanja s pomoću kibernetičkih načela racionalnosti sustava i okoline (informacija - povratna sprega - kontrola - komunikacija) (Paić, 2020; Stiegler, 2015). ${ }^{4}$

Moć nije ništa drugo negoli sinteza političkoga i politike u geopolitičkome upravljanju onime što Schmitt naziva velikim prostorom. Takav prostor nadilazi dosadašnje granice, teritorijalne i kulturalne, međunarodnog poretka država. Biti izbačen u rasprostiranje i spacijaliziranje znači nužno razotkrivati eksteritorijalna mjesta za djelovanje izvan dosadašnjega modela zakona (Lex) u pravu nacionalnih država. Kad bi preseljenje svih tzv. pregnantnih pojmova moderne teorije države za Schmitta bilo tek djelovanje drugim sredstvima u tom globalno-planetarnome prostoru s onu stranu zemlje i na morima i na nebu među satelitima, mogli bismo govoriti o svojevrsnome kontinuitetu modernoga shvaćanja razdvajanja društva i države u dijalektičkome smislu očuvanja i dokidanja-prevladavanja (Aufhebung) suprotnosti. Schmitt bi time potpisao trijumf Hegela u suvremenosti. No, znamo da je u prepisci s Kojèveom 1950-ih godina jasno vidio, kao uostalom i autor knjige Kako čitati Hegela, da je s njegovim nasljeđem u filozofiji politike, države i prava svršeno, i to ne samo zbog Marxove kritike države već ponajprije zbog obrata u biti onoga što Kojève naziva krajem povijesti s dolaskom razdoblja svojevrsne post-politike upravljaštva svijetom kao proširenom kapitalističkom korporacijom. Schmitt je bio suglasan s tim stavom. No, ipak je vidio u pojmu političkoga i politike nešto Unheimliche, gotovo nužnost da se čovjek kao zoon politikón umjesto borbe oko etičko-moralnoga, estetskoga i ekonomskoga priznanja vlastite osobnosti dokazuje u onome što je neodredivo bilo kakvim upućivanjem na prvi uzrok i posljednju svrhu djelovanja. Drugim riječima, Schmittu se činilo nemogućim dokinuti uvjete

${ }^{4}$ Koliko je za uvid u globalizam nužno promijeniti ne samo jezik ekonomije i politike pokazuje nam uporaba riječi svijet. Nije, naime, slučajno da se osobito u francuskome otporu amerikaniziranju 'svijeta' u svim mjerodavnim teoretskim radovima filozofa, sociologa, politologa, antropologa rabi izraz mondijaliziranje umjesto globaliziranja, iako više nije posve jasno na što se riječ monde u smislu svijeta uopće odnosi. Ako to nije horizont značenja u smislu hermeneutike povijesti s jasnim razlikovanjem antičkog od modernoga svijeta, od uporabe riječi mundus na latinskome do onoga što je osobito bilo odlučujuće u promišljanju Husserla i Heideggera s obzirom na riječi kao što su svijet života (Lebenswelt) i svijet u okviru četvorstva zapadnjačke metafizike (bitak - bog - svijet - čovjek), o čemu onda govorimo kad kažemo još - svijet? Mi više ne živimo u svjetsko-povijesnome događaju otvorenosti svijeta, nego u mnoštvu različitih autopoietičkih svjetova. Sve te svjetove određuje njihova pragmatika znanja i modusi interaktivne komunikacije. Uz Schmitta, u suvremenom političkome mišljenju ovu je postavku izričito zagovarao sociolog Niklas Luhmann (2002). 
mogućnosti povijesti kao što su to države i njihovo uzdignuće u imperijalne poretke a da se bestemeljnome temelju svakog zamislivoga povijesnoga događanja ne odredi drukčiji egzistencijalni način zajedničkoga bitka s onu stranu svođenja političke borbe na ekonomsko natjecanje na tržištu (De Vries, 2001, str. 92, 105; Paić, 2017, str. 163-218).

Kako se i na koji se način nakon epohe nacije-države i kraha europskoga imperijalizma, što je bila i ishodišna postavka Hanne Arendt u njezinim Izvorima totalitarizma, uspostavljaju uvjeti mogućnosti političkoga djelovanja koje više nema za svoj egzistencijalni prostor ideju ukorijenjenosti u naciju kao državu s mehanizmima zaštite suverenosti s pomoću zakonodavne, izvršne i sudske vlasti zapisane u ustavu? Je li u pravu Giorgio Agamben kad na tragu Schmitta iz Političke teologije zagovara stav o djelovanju suvremenih demokracija u permanentnom izvanrednom ili iznimnome stanju, a koje iziskuje neprestani čin neutraliziranja i suspendiranja pravne norme u korist odluke kao kontingentnoga čina (Agamben, 2005)?

\section{Političko kao odluka i politika kao stanje}

Danas povratak Schmittu nije, kako bi se to moglo na prvi pogled pomisliti, motiviran jedino uvidom kako je nastupilo razdoblje entropije i neutraliziranja političkoga u ime ekonomiziranja društva i njegova tehnologiziranja svim mogućim sredstvima. Da je s njegovim temeljnim postavkama iz prve faze političkoga mišljenja, koje ponajbolje odražavaju spisi Pojam političkoga i Politička teologija, moguće ontologijski rastemeljiti logocentričnu i racionalnu povijest metafizike i unutar nje diskurs političke filozofije od Aristotela do Hegela, čini se gotovo samorazumljivim. Otklonimo li neprestanu sjenu nacizma i antiliberalizma što natkriljuje pristup njegovu političkome mišljenju, a ne teoriji države i prava kao pozitivizma i normativizma što je on sam kritički prigovarao suvremenicima, razvidjet ćemo nešto uistinu neporecivo. To je ono što po analogiji vrijedi i za sudbinu filozofijskoga mišljenja Martina Heideggera, čak i u znatnijoj mjeri zbog njegove odlučujuće uloge u suvremenoj filozofiji i povijesti ideja. Heideggerova je metapolitika "duhovnoga nacizma" nedvojbeno njegov etičko-politički crimen u svim raspravama o biti političkoga i politike te mogućnosti nadolazeće zajednice, kao što je Schmittovo opravdanje neoimperijalizma nakon propasti nacizma, komunizma i europskoga poretka nacija-država 1945. godine sporno mjesto njegove geopolitike Großrauma. ${ }^{5}$ Vidjet

5 “Zašto uopće iznova toliki povratak Schmittu i, paradoksalno, preko njega Hobbesu i Rousseauu osobito u zastupnika tzv. repolitizacije i agonalnoga pluralizma (Derrida, Agamben, Mouffe i drugi)? Odgovor je u tome što se njegova vizija nadolazećega doba i svjetskoga poretka realistički suočava s krajem modernosti i njezina političkoga kulta - nacionalne države. S krajem nacije-države suverenost postaje pitanje koje izlazi iz okvira teorije države i prava. Umjesto metafizike normi sada je obrat u tome što decizionizam političke egzistencije uspostavlja sam do- 
ćemo kako je to upravo Hannah Arendt kritički osvijetlila baveći se u svojim marginalijama analizom Schmittova Nomosa. Što je u ovom sklopu problema temeljni razlog za uvid kako više gotovo ni jedan tradicionalno određeni pojam iz političke filozofije ne može izdržati ispit vjerodostojnosti u globalno-planetarnim uvjetima života suvremenosti? Ništa drugo negoli postavka da je političko kao odluka uvjet mogućnosti politike kao stanja. Prvo, naime, pretpostavlja slobodu egzistencijalnoga rizika djelovanja po cijenu poraza ili propasti ljudskoga identiteta u zajedničkome svijetu onog što se u moderno doba nazivalo oprekom građanskoga društva i države, dok se drugo odnosi na faktično stanje uspostavljanja pravnoga poretka kojem u načelu stoji iznad svih konkretnih situacija neka vrsta sekulariziranoga božanstva politike - ustav.

Odluka odlučuje o stanju stvari, ne obratno. Ovaj decizionizam odgovara u filozofiji pojmu imanencije. Bog nije nadležan za opravdanje odluke iako se narodi i države kroz medijske nastupe svojih suverena uvijek rado pozivaju na neke od njegovih neobrazloženih ideja, kao što je primjerice pravednost u okružju židovske eshatologije. Sjetimo se, primjerice, naziva vojno-redarstvene akcije američke vojske protiv mreže terora al-Qaede nakon 11. rujna u Afganistanu i Iraku nazvane "Beskonačna pravda" gotovo istovjetno temeljnom pojmu ranoga Emmanuela Lévinasa iz njegove etičke perspektive traganja za bezuvjetno Drugim (Lévinas, 2009). Stoga nije nipošto začuđujuće da je Schmitt u Političkoj teologiji zauzeo stav o onome što takvo normalno stanje vladavine u liberalno-demokratskoj ustavnoj državi i kapitalistički vođenome i organiziranome građanskome društvu dovodi u pitanje. Iznimno stanje jest, dakle, izvanredna situacija. S njom dolazi do nužnosti suspendiranja pravnoga mehanizma kojim suverenost naroda kao fikcija novovjekovne političke teorije od Bodina i Rousseaua ima svoje bitno mjesto razgraničenja od tzv. prirodnoga stanja. Otuda je za Schmitta takvo izvanredno stanje (Ausnahmezustand) kontingentni događaj kojim političko dokazuje primat pred normativnopravnim uvjetima vladavine u liberalno-demokratskim sustavima upravljanja državom. Razlikovanje između vladanja i upravljanja ovdje se pokazuje odlučujućim mjestom posredovanja ideja koje su u 20. stoljeću dovele do sloma modernoga poretka nacija-država. U Schmittovoj Političkoj teologiji II drugo poglavlje ima podnaslov na francuskome le roi règne et ne gouverne pas, kralj vlada, a ne upravlja (Schmitt, 2019a, str. 109). Vladati znači biti na dispoziciji već postojećim formama vladavine u državi od demokracije, republike, tiranije, diktature. Sve što je u tom

gađaj obrata političkoga u središte promišljanja. Odluka suspendira normu. Akcija mijenja vrijednosti. Sve postaje neodređeno i neizvjesno kada u igru ulazi sam događaj radikalne promjene svijeta. Statičnost nacije-države u svjetskoj povijesti zamjenjuje dinamičnost i fluidnost mreže neoimperijalne suverenosti. Svi klasični politički subjekti/akteri modernoga doba gube svoju moć da bi ih preuzelo nadzorno društvo u globalitarno doba" (Paić, 2013, str. 95). 
smislu od Aristotela do Lea Straussa vezano uz artikulaciju političke moći u državnome poretku skrojenom prema aritmetičkim i geometrijskim načelima, a u novovjekovnoj političkoj teoriji to je i metoda koju rabi Spinoza u Teologijsko-političkoj raspravi, odnosi se na mogućnost vertikalno-horizontalnoga smjera prijenosa moći s Boga na kralja-cara-kneza do naroda kao mnoštva. Logika vladavine jest jasna nadređenost-podređenost u strožim ili manje strogim modelima odlučivanja o bitnim pitanjima suverenosti. Ne može se vladati Drugime bez uspostavljanja načela kojim se vladavina održava povijesno-epohalno kao Moć koju nitko ne osporava, čak ni u najslobodnijim, libertinskim demokratskim sustavima. No, sve je to još uvijek samorazumljivo za političko stanje, koje forme vladavine od rojalizma do diktature, kako je to izrekao Schmittov omiljeni teoretičar politike, španjolski katolički rojalist Donoso de Cortés, uzdižu do temelja onoga što stoji u biti političkoga kao uvjeta mogućnosti svake vladavine, a to je decizionizam. Schmitt u Političkoj teologiji o tome kaže:

Rojalizam više ne postoji, jer više ne postoje kraljevi. Stoga više ne postoji legitimitet u baštinjenom smislu. Sukladno tome, za njega preostaje samo jedan rezultat: diktatura. Rezultat je to do kojeg je došao i Hobbes, iz iste, premda s matematičkim relativizmom pomiješane konzekvence decizionističkog mišljenja. Auctoritas, non veritas facit legem. [Pravo stvara autoritet, a ne istina.] Opširnije izlaganje tog decizionizma danas ne postoji, kao ni primjereno priznanje Donoso Cortésa. Ovdje možemo napomenuti samo da Španjolčev teološki pristup ostaje sasvim na liniji srednjovjekovnog mišljenja, čija je struktura pravna. Sve njegove percepcije i svi njegovi argumenti pravni su do u posljednji atom, tako da na matematičku prirodnoznanstvenost 19 . stoljeća gleda s istim nerazumijevanjem $\mathrm{s}$ kojim i ta prirodnoznanstvenost gleda na decizionizam i specifičnu upečatljivost pravnog mišljenja, koje kulminira u osobnoj odluci (ibid., str. 54-55).

Ako je diktatura logična posljedica onoga što dolazi nakon rojalizma, kako je to i bilo u 20. stoljeću u Španjolskoj nakon kraja građanskoga rata s vladavinom generala Franca, onda valja posebno istaknuti sljedeće. Schmitt u pravilu ne govori o konkretnim, singularnim slučajevima iz povijesne prakse, iako je čitav niz njegovih pravnih spisa posvećen parlamentarizmu, ustavnoj državi, demokraciji i diktaturi. Ono što nadilazi ovu naizgled determinističku tvrdnju Cortésa s tipom vladavine koja nadomješta doba suverenih kraljevstava u Europi jest ponajprije jasno razlikovanje vladanja kao raspolaganja političkom moći unutar ove ili one forme države koja je u načelu realizacija novovjekovnoga shvaćanja suverenosti kao neograničene vladavine monarha ili naroda. No, kad se pojavljuje ono što određuje pojam upravljanja i upravljaštva (gouvernmentalité), kako je to precizno pokazao Foucault s pojmom dispozitiva moći, više se ne mogu održati klasični pojmovi teorije države i prava (Lemke, 2019). Razlog valja vidjeti u tome što upravljanje i 
upravljaštvo proizlaze iz uspostavljanja Moći s onu stranu razlikovanja građanskoga društva i države. Politička ekonomija umreženog kapitala kojim upravlja korporacija već je u 20. stoljeću dovela do nastanka neoliberalizma kao najvišega stadija preobrazbe ekonomije u totalnu politiku tehnosfere. Ona kibernetički organizira cjelokupni život ljudi u onome što još uvijek nazivamo društvima i državama. Od ranoga do kasnoga Schmittova političkoga mišljenja možemo slijediti misao koja se smatra njegovom kritikom liberalizma u najširemu mogućem smislu. Riječ je o stavu da je modernost kao i liberalizam uvjet mogućnosti redukcije samoga političkoga djelovanja na tehno-ekonomske odrednice koje pokazuju kako smo suočeni s preobrazbom svrhe političkoga u sredstvo, navlastito ono koje sav patos i egzistencijalnu odlučnost čovjeka svodi na interese profita kapitalističke korporacije. No, neporecivo je da je posrijedi upravo ono što je prvi uvidio Schmitt u svojoj radikalnoj kritici liberalizma i svođenja onog političkoga, dakle decizionizma, na prirodoznanstvene metode racionaliziranja, kvantifikacije i susprezanja tzv. ljudske prirode na logiku stroja. Upravljanje kao ekonomsko-tehničko upravljaštvo jest vladavina menadžmenta kao psiho-marketinga u vođenju suvremene politike koja s idejama pravednosti, slobode, jednakosti i solidarnosti nema ništa zajedničko. Umjesto toga, svjedoci smo kako ova biokibernetika Moći postaje nova forma neoimperijalizma u velikome prostoru, šmitovski rečeno Großraumu.

Je li alternativa tom permanentnom izvanrednome stanju koje se ovjekovječuje u stalnoj konstrukciji novih neprijatelja i neprestano novim savezima privremenih prijatelja na globalno-planetarnoj razini borbe imperija uistinu moguća bez dekonstrukcije ne samo ideje političkoga i politike kao decizionizma već ponajprije ideje suverenosti u doba vladavine pluriverzuma svjetsko-povijesnih moći u formi postnacionalnih država? Schmittove su postavke u prvoj fazi njegova političkoga mišljenja nesumnjivo smjerale tome da iz logike iznimnoga ili izvanrednoga stanja otvore prostor mišljenju događaja kao neproračunljive kontingencije slobode s onu stranu svakog liberalno-anarhističko-marksističkoga shvaćanja individuuma. Usto, čitava je njegova radikalna polemologija i decizionizam unatoč polemici s političkom romantikom nešto bitno drukčije od zagovora teologijsko-političke obrane katolicizma, iako je baš on vjerojatno najznačajniji predstavnik protuprosvjetiteljstva u političkome mišljenju 20. stoljeća (Löwith, 1984; Otmann, 2010). Kad je riječ o alternativi, tu uistinu nema mjesta mistifikaciji. Nikakav povratak tzv. neliberalnim demokracijama ili, pak, pseudo-teokratskim formama hibridne vladavine uz pomoć Crkve u suvremenim imperijima, koje sve povezuje logika postimperijalne suverenosti unatoč razlikama u ideologijsko-političkim ciljevima opravdanja težnje za apsolutnom Moći, ne znači ništa drugo osim proizvodnje privremenog kaosa i anomije. Suvremeni svijet je, a to je Schmitt jasno vidio u tendencijama znanosti, tehnologije i kulture, na putu ulaska u razdoblje totalnoga upravljanja s onu stranu 
razlike građanskoga društva i države (Schmitt, 1932). Pitanje je samo kako i na koji način još uvijek očuvati moć onog političkoga i politike u tome megastroju biokibernetičkoga upravljaštva kad ni Bog, ni revolucije i proturevolucije više nisu stvar 21. stoljeća. Ako je posve jasno da u decizionizmu stvar suverenosti proizlazi iz postavke kako je "suveren onaj koji odlučuje o iznimnom stanju" (Schmitt, 2019a, str. 13), onda iz toga treba očitati mogućnost da se binarne opreke vladanja i upravljanja postave na razinu ontologijski izvedene politike. Ona, naime, za svoj predmet nema više nikakvo neokantovsko shvaćanje primata norme i zakona nad odlukom, u smislu vladavine transcendencije nad imanencijom. Posve suprotno, kad je uzdrman čak i taj veličajni i nedodirljivi pojam suverenosti s kojom je novovjekovna teorija države i prava bila izravno usmjerena spram Boga kao kralja i naroda na Zemlji, postaje jasno kako decizionizam i Moć tvore binarnu logiku djelovanja suvremene politike, a ne pojam pravednosti i slobode individuuma u zajednici (Schmitt, 2018). Paradoks Schmittove kritike neokantovskoga pravnoga normativizma i pozitivizma u pravu je u tome da je ono što je radikalno podvrgao kritičkome stajalištu, dakle liberalizam kao metafiziku sekularizirane vladavine tehnike i ekonomije u vidu modernoga kapitalizma, zapravo uvjet mogućnosti vladavine kao upravljanja velikim prostorom $\mathrm{u}$ doba postimperijalne suverenosti.

Odgovor na pitanje što je postimperijalna suverenost označava istodobno dvostruku dekonstrukciju: prvo, ideje imperija u tradicionalnome shvaćanju proširenja nacije-države i kolonijalnoga zauzimanja prostora unutar i izvan geografskokulturalne zone utjecaja koje se definira pojmom 'nacionalnoga interesa', osobito Europe u moderno doba i SAD-a od 1945-2001. godine i, drugo, ideje suverenosti naroda kao subjekta političkoga oblikovanja moderne države kakva se uspostavila u Europi od 18. stoljeća do kraja I. svjetskoga rata. Obje, i ideja imperija i ideja suverenosti stoga više nisu moguće na pretpostavkama teritorijalne i etničke homogenosti. Vladati velikim prostorom znači neprestano ga razmještati ekonomsko-političkom i kulturalnom spacijalizacijom, pri čemu je posve jasno da ono što preostaje kako od imperija tako i od suverenosti nije ništa drugo negoli nova strategija upravljanja prostorom koji je formalno de-kolonijaliziran, ali stvarno izručen na milost i nemilost geopolitičkih posezanja za prirodnim i ljudskim resursima onih država koje pripadaju tzv. trećem svijetu. Postimperijalna suverenost označava preobrazbu vladanja nad prostorom Drugih u sustavno upravljanje novim teritorijima izvan tradicionalne nadležnosti tzv. suverene države. Uostalom, o ovom sinkretičkome pojmu političke dekonstrukcije moderne ponajbolje svjedoče ratovi 21. stoljeća, jer to više nisu klasični nacionalno-državni sukobi, već logika djelovanja, šmitovski rečeno, saveza prijatelja protiv neprijatelja kao tzv. rogue states, ili označenih kriminalnih država u mreži terora i političkih religija kao legitimacijske moći suprotstavljanja tzv. novom svjetskome poretku (Derrida, 2005; Paić, 2013, str. 63-99). 
Rekao bi Hegel, lukavstvo uma povijesti ogleda se u preobrazbi duha u njegove suprotstavljene likove od religije, umjetnosti i filozofije. U ovom slučaju, ideja imperija i imperijalizma s kojom Schmitt otpočinje svoju drugu fazu mišljenja integrira njegove postavke o političkome i politici kao odluci o iznimnome ili izvanrednome stanju. Problem je samo u tome tko odlučuje o uspostavljanju takva stanja ako ne upravo imperij slobode i tržišne metafizike kao što je to SAD, a nakon toga istu logiku samo slijede njegovi neprijatelji poput Rusije i Kine.

Dva su korelativna pojma pritom presudna za razumijevanje biti političkoga kao odluke i biti politike kao pravnoga stanja (Rechtzustand). To su iznimka i događaj koje Schmitt opisuje kao sekularizirani pojam čuda Božjega. No, stvar postaje transparentnija kad na scenu stupa rezultat ove preinake teologije u politiku, a riječ je o diskurzivnoj moći novih pojmova kao što su to čovječanstvo i povijest.

Najviša i najsigurnija realnost stare metafizike, transcendentni Bog, bila je uklonjena. Važnije od razmirice među filozofima bilo je pitanje tko je preuzeo njegovu funkciju kao najviša i najsigurnija realnost, a time i posljednja legitimacijska točka u povijesnoj stvarnosti. Dvije nove ovostrane realnosti nastupile su i etablirale jednu novu ontologiju, ne čekajući završetak spoznajno-teorijske diskusije: čovječanstvo i povijest. Sasvim irealno, promatra li ih se logikom racionalističke filozofije 18. stoljeća, ali objektivno i evidentno u svom nadindividualnom važenju, one su in realitate ovladale mišljenjem čovječanstva kao dva nova demijurga. Prvi, ljudsko društvo, postao je aktivan u različitim likovima, kao narod, zajednica, čovječanstvo, ali uvijek u istoj revolucionarnoj funkciji (Schmitt, 2019b, str. 83).

Za Schmitta je odluka formalno bezrazložna ili bestemeljna, iako je njezino podrijetlo vezano uz okazionalizam Božje instancije kojom se svijet u svoja dva modusa, sakralnome i sekularnome, otvara čovjeku kao prostor borbe za priznanje naroda u svjetskoj povijesti. Znamo da je i za Hegela to bilo poprište borbe svjetskog duha kao borbe suverenih država za moć u okviru razdiobe moći svjetskih carstava. Schmittov pojam političkoga zbog toga je usmjeren protiv negiranja smisla države. Umjesto liberalističkoga shvaćanja slobode polazeći od individuuma, ovdje je posrijedi sloboda kao uvjet mogućnosti postojanja naroda kao državotvornoga entiteta. Egzistencijalno-decizionistički obrat, prema mojem sudu, čini se bitnim, zbog čega Schmittov pojam političkoga ne možemo proglasiti opravdanjem bilo kakve diktature ili totalitarizma. Zašto? Zbog toga što odluka počiva na praznom središtu slobode, a ne moći. Što će biti od naroda i država u areni svjetske povijesti ovisi o njihovoj snazi, mudrosti, sposobnosti preživljavanja, intelektualnoj i estetskoj razini uspostavljanja svih potrebnih prerogativa vlasti koji omogućuju elementarno jamstvo da neće biti izbrisani iz povijesti poput crne mrlje. Političko je, dakle, sudbonosni događaj egzistencijalno shvaćene slobode kao javne činjenice. Zato Schmittova razdioba politike na figure prijatelja i neprijatelja ne znači nikakvo 
depolitiziranje u smislu ulaska privatnoga u prostor političkoga. Ne postoje privatni prijatelji i neprijatelji države, već samo obznanjeni protivnici koji u određenom kontekstu i situaciji postaju javno određene mete međunarodnog djelovanja unutarnje i vanjske politike. Ovaj hobsijanski prikaz stanja stvari s politikom u 20. stoljeću nastavlja se i danas istim intenzitetom. Uz neizbježni dodatak da živimo u doba kraja ideje nacije-države klasičnoga pojma suverenosti te da upravo ovo doba, osim vladavine permanentnog izvanrednoga stanja, pokazuje i tendenciju upravljaštva. Time transnacionalne korporacije zauzimaju teritorije zemlje dijeleći profit od investiranja u izvore kapitala spregom ekonomije i rata u svim aspektima preobrazbe realnoga u virtualno. Ratovi su profitabilno reinvestiranje u industrijski pogon tehnoznanosti i informacijsko-komunikacijskoga sektora postmoderne ekonomije. No, njihova je bit u tome što otvaraju prostor za teritorijaliziranje/reteritorijaliziranje kapitala kao imanentnoga događaja umrežavanja subjekata/aktera globalne politike razdiobe zemlje (Alliez i Lazzarato, 2016).

U polemičkome diskursu Schmitt postaje neskriveni prethodnik političkih obrata u smjeru kontingencije, singularnosti i metapolitike. Pritom je razvidno da se razlog ove neprestane igre pronalaženja duhovnoga srodnika postfundacionalizmu suvremenosti u mišljenju Heideggera i Schmitta, kad je riječ o teoretičarima poput Badioua, Nancyja, Leforta i Agambena, može izvesti iz korelacije egzistencijalne odluke djelovanja koja sabire u sebi vremensku dimenziju sadašnjosti u nadolazećoj budućnosti i uspostavljanja posve drukčijeg stanja politike izvan redukcije na pravni normativizam i pozitivizam. U svakom slučaju, aporije političkoga i politike u doba postimperijalne suverenosti proizlaze otuda što se u permanentnome produljenju logike izvanrednoga stanja ono što čini bit iznimke, a to je djelovanje bez tradicionalnoga subjekta moderne nacije-države, upisuje u mrežu označitelja koji svi imaju neoimperijalni fluidni identitet, a određuje ga pojam kulture ili civilizacije. Dakako, s državom se više ništa konkretno ne može, nikakav pothvat koji bi jamčio izvjesnost narodu kao subjektu suverenosti, pa se stoga ratovi i vode u 21. stoljeću kao regionalni sukobi, kao vojno-redarstvene intervencije NATO-saveza, kao sukobi umreženih konglomeracija moći Zapada protiv tzv. kriminalnih država (rogue states) (Derrida, 2005). Sve postaje hibridno i nadomjestivo, jer je teritorijalno omeđena neograničena vlast $u$ doba monarhija i rojalizama zapadne Europe od kasnog srednjega vijeka do I. svjetskoga rata ništa drugo negoli romantična fikcija. Nije to samo u političkome smislu. Pogledamo li kako i velegradovi 21. stoljeća nisu ništa drugo negoli arhitektonski prijepisi korporativne ekonomije-politike-kulture kao umreženoga društva spektakla i kontrole, te kako se njihovo širenje ne zbiva na malom prostoru, već u bezdanu pustinjske spacijalizacije koja prodire već duboko u riječne i morske pojaseve, razvidjet ćemo nešto uistinu čudovišno, Unheimliche (Paić, 2019). Iza svega ne stoji više nikakav transcendentni vrhovni Označitelj poput 
Boga ili Naroda, Čovječanstva ili Civilizacije. Kapital je postao imanentna transcendencija bezuvjetnog napretka i razvitka s onu stranu Zemlje. Kao čista totalna mobilizacija ništavila svaka izgradnja nužno je svagda i razgradnja, kao što je svaki mir ništa drugo negoli nastavak rata drugim sredstvima. Za to je prava potkrepa pojam političkoga Carla Schmitta na ishodu doba državnosti i njezine metafizike Ius Publicum Europaeum.

Vratimo se nakratko početku ovog razmatranja. Rekli smo kako se suočavamo s povratkom mitskoga i religioznoga u političkome i politici. Naposljetku, sam je Schmitt svojim pojmom političke teologije početkom 1920-ih godina pridonio nastanku niza srodnih, ali bitno različitih promišljanja istoga fenomena u djelima Waltera Benjamina, Hanne Arendt, Erica Vogelina i Jacoba Taubesa. Ako se ovo mitsko shvaćanje decizionizma kod ranoga Schmitta svede na pravu mjeru iskaza, tada možemo govoriti o tome da je ovaj korak natrag u prostor egzistencijalnoga hoda po rubu teorije države i prava, jer Schmitt je po struci bio ipak ustavni pravnik, istodobno i najradikalnija kritika dvojeg. S jedne je strane posrijedi kritika Hegela zbog njegova svođenja politike na logiku djelovanja subjektivnoga i objektivnoga duha, iz čega je izostao moment zbiljske, žive djelatnosti polemički i strasno angažiranoga pojedinca kao pripadnika naroda i države u smislu singularizacije, a ne fiktivne univerzalnosti. S druge, pak, strane, kritika je upućena korifejima pravne znanosti koji su pravo kao normu pretpostavili događaju jednokratne i neponovljive odluke koja mijenja čitavu strukturu normalnog parlamentarnoga života u ustavnoj državi. Cilj je, dakle, dovesti u pitanje vrhunac filozofije prava i države u Hegelovoj apsolutnoj metafizici te pravnu pozitivnu znanost zbog toga što je političko podredila i suspregla pod birokratsko-zakonske okvire. No, krajnji cilj rastemeljenja ove logocentrične teorije politike s Hegelom i neokantovcima u pravnoj znanosti bio je pokušaj, uistinu srodan Heideggerovu mišljenju, pronalaženja alternative tehničkome pogonu prirodoznanstvenoga svođenja zbiljskoga političkoga djelovanja na nešto političkome izvanjsko kao što su to autonomna područja ekonomije i tehnologije. Schmitt je prvi mislilac političkoga i politike u suvremenosti koji je jasno vidio kako je sloboda ljudske egzistencije čin političkoga iracionalizma, a ne tek uzvišene moći racionaliziranja i konsenzusa demokratske javnosti. Mit otuda nije nešto zastarjelo i opsjenarsko, jer temeljne riječi zapadnjačke metafizike u Grka i Rimljana, potom u skolastičkome srednjovjekovlju i novovjekovnim postulatima mišljenja nisu ništa odavno prošlo, osim što im se značenje povijesno mijenja. Tako je, naposljetku, i s ključnim pojmom geopolitike za postimperijalno shvaćanje suverenosti kao što je to nomos. 


\section{Nomos i njegove mračne tajne}

Schmittova konačna pozicija u političkome mišljenju nedvojbeno je vezana uz njegovo zacijelo najintrigantnije djelo uopće. Objavio ga je 1950. godine kad je već raskrstio s iluzijom da bi pojam političkoga u smislu apoteoze države i doba državnosti moglo još imati neku ulogu u nadolazećem razdoblju svjetske povijesti. Ako su temeljni pojmovi koje je Schmitt razvio u prvoj fazi mišljenja 1920-ih i 1930-ih godina bili iznimno ili izvanredno stanje, suverenost, politička teologija, prijateljneprijatelj kao četvorstvo njegove okazionalističke političke ontologije, onda je druga faza Schmittova mišljenja u znaku navlastitoga shvaćanja geopolitike kao uvjeta mogućnosti neoimperijalizma. Što ova promjena teorijskoga ishodišta treba značiti za razumijevanje političkoga i politike u globalnome poretku vladavine tzv. novog svjetskoga poretka? Oni koji u tome vide tek obrat od egzistencijalne problematike djelovanja $u$ situaciji izvanrednoga stanja naspram prostorne protežnosti u stvaranju novih kolonija u svijetu tek su djelomice u pravu. Moglo bi se čak pronaći dodirnih točaka između pojma geofilozofije ${ }^{6}$ u djelu kasnoga Deleuzea i Guattarija $s$ obzirom na pojmove teritorijaliziranja/reteritorijaliziranja s onim što Schmitt naziva Großraum u nastojanju da se taj planetarno-globalni prostor razdijeli i postane prisvojenim vlasništvom u okviru nove postimperijalne suverenosti na temelju dekonstrukcije američke hegemonije nakon II. svjetskoga rata (Meierhenrich i Simons, 2017). Ipak, nećemo u ovome razmatranju tražiti ni analogije ni srodna mjesta između posve različitih pristupa razumijevanju političkoga i politike u suvremenosti. Ono što ne možemo izbjeći jest priznanje činjenice da se Schmitt prvi u okviru političkoga mišljenja 20. stoljeća preusmjerio u određenje geopolitike izvan tradicionalnoga shvaćanja ovog pojma, koji je bio odlučujući za nacistički imperijalizam, ali isto tako u drugome svjetlu i za američko i rusko posezanje za teritorijima od tzv. nacionalnoga interesa. Prostor kao spacijaliziranje u smislu zauzimanja i dijeljenja teritorija postaje presudan nakon kraja II. svjetskoga rata te osobito u 21 . stoljeću. U "Proslovu” Nomosa zemlje Schmitt kaže:

${ }^{6}$ Pojam geofilozofije Deleuze i Guattari razvijaju u 4, poglavlju spisa Što je filozofija? Pritom pokazuju da je iskustvo zemlje od samih početaka u Grka do modernoga kapitalizma Engleske i njezina nastavka u SAD-u kao predvodniku globaliziranja rezultat činjenice da je riječ o neprestanom procesu stabiliziranja i transformacije prostora kao uvjeta mogućnosti nastanka filozofije, demokracije, znanosti, umjetnosti, kulture. Prostor nije ništa drugo negoli odnos između teritorijaliziranja i reteritorijaliziranja, a utemeljitelj ovog pojma, naime geofilozofije, Nietzsche imao je na umu kritički dijalog između forme moderne nacije-države i univerzalnosti koja partikularnoj kulturi, primjerice, Nijemcima, Francuzima, Englezima, daje pravo na utiskivanje moći u samom procesu kojim filozofija postaje moć mišljenja i tako utječe svojim konceptima na druge forme duhovnih djelatnosti (Deleuze i Guattari, 2017, str. 67-88). 
Prethodni, europocentrični poredak međunarodnog prava raspao se. S njim se raspada i drevni nomos zemlje. Sve je to nastalo iz nevjerojatnog, neočekivanog otkrića novog svijeta, iz neponovljivog povijesnoga događaja. O modernome ponavljanju se moglo razmišljati samo u fantastičnim paralelama, nešto poput onoga kad ljudi otkriju novo, do tada potpuno nepoznato svemirsko tijelo na putu do Mjeseca... Na pitanje o novome nomosu zemlje ne može se odgovoriti s takvim maštarijama. Isto tako se to neće riješiti daljnjim znanstvenim izumima. Razmišljanje ljudi mora se ponovno usmjeriti na elementarne poretke svekolikog zemaljskoga postojanja. Mi tragamo za smislom zemlje (Schmitt, 1974, str. 4).

Europa završava svoje poslanstvo u političkome smislu koje joj je od Grka i Rimljana, polisa i republike, srednjovjekovnoga kršćanstva i novoga vijeka s idejom kozmopolitske zajednice u Kantovoj filozofiji države i prava tradicijom određeno kao sudbina. Schmitt jasno ukazuje na to da je s krajem metafizike, kako je on vidi, nastupilo doba kraja europocentrizma i iz njega izvedenog sustava međunarodnoga prava. Ono što slijedi jest uspostavljanje "novoga nomosa zemlje". Iako se sve u ovom navodu čini toliko jednostavno i samorazumljivo, ipak je nešto u najmanju ruku problematično. Naime, ništa drugo negoli najava da smisao traganja za zemljom postaje ujedno politička i pravna zadaća nakon što je ono "novo", a pod time se ne misli samo na Kolumbovo otkriće Amerike, već i na ideje napretka i razvitka novovjekovnih znanosti i tehnike, poprimilo značenje ontologijskoga postulata. Nije Schmitt usamljen u nastojanju da političko mišljenje, figurativno rečeno, prizemlji. Uz njega najistaknutije mjesto zauzima Hannah Arendt. Vidjet ćemo, uostalom, koliko je i njezina postavka o imperijalizmu kao logičnoj konzekvenciji raspada poretka nacionalnih država u Europi nakon I. svjetskoga rata odlučujuća za promišljanje tzv. posthistorijske situacije kada ljudska prava manjina i nepriznatih raseljenih ljudi bez države postaju ispit vjerodostojnosti svake teorije o suverenosti danas (Agamben, 2000, str. 15-28). Nakon uvida u kraj epohe država i državnosti, ali ne i etnosa kao izvora kulturnoga identiteta naroda u suvremenome razdoblju vladavine Großrau$m a$, što drugo preostaje osim potrage za nadomještanjem države u ideji imperija? Za veliki prostor nisu više održive fikcije europocentrizma o nacionalnim državama kakve su se razvile, s jedne strane, na prostorima sjevera i juga kontinenta te Sredozemnoga mora i, s druge, u prvoj pomorskoj sili modernoga kapitalizma kakva je bila Velika Britanija. Umjesto toga, susrećemo se s praznim mjestom Moći. Ono se mora orijentirati tako da bude jedinstvo poretka i uprostorenja (Ordnung und Ortung).

Poredak u smislu političko-pravnoga uvjeta mogućnosti vođenja geopolitike ima logičko-povijesno prvenstvo nad prisvajanjem i razdiobom prostora kao teritorija (Schmitt, 1974, str. 13-20). Zanimljivo je, nadalje, da Schmitt u ovome djelu govori o pred-globalnome međunarodnome pravu. Ono je rezultat saveza država kao suverenih monarhija koje su u 17. stoljeću uspostavile znameniti i ujedno krhki 
Westfalski mirovni ugovor kojim je nastupilo relativno stabilno razdoblje za uspon kapitalizma, kao i za nastanak složenih ekonomsko-političkih sveza građanstva i aristokracije u oblikovanju prosvjetiteljsko-liberalnih okvira i njihovom djelovanju unutar i izvan nacionalnih granica Europe. Nije to samo povijesni trenutak početka moderne politike kao normativne metafizike državnoga prava. Daleko je od toga važnije kako se pojam suverenosti države odnosi na mogućnost stabilnosti unutar teritorijalnih granica koje su, doduše, krhke, ali i jamstvo stabilnosti. Iako je Schmitt radikalni kritičar liberalizma, te se i u Nomosu zemlje govori o kršćanskome pojmu katechona u političko-teologijskome značenju zadržavatelja Antikrista, što znači da je posrijedi mišljenje koje smisao političkoga djelovanja vidi u odluci o putu eshatologijskoga iskupljenja čovjeka, ne može se poreći ovo realističko stajalište glede stabilnosti Europe tijekom burne povijesti (ibid., str. 25-36). Ako je političko autonomno područje ljudske egzistencije, bjelodano je da ono ne može imati svoj temelj isto tako kao ni sloboda. To je glavni razlog zašto odnos između transcendentnoga Boga i bitka (političkoga) u smislu djelovanja valja odrediti kao "okazionalni decizionizam", kako je to prvi interpretativno pokazao Karl Löwith u svojem tumačenju Schmittova političkoga mišljenja (Löwith, 1984). Stoga su sveza i odnos Boga i proturevolucije u političkome i politici nužno paradoksalni i aporetični. Izbačaj u Großraum zahtijeva ispunjenje temeljnih zadaća i ciljeva vladavine imperija kao upravljanja novim kolonijalnim prostorom, koji se neprestano zauzima ili okupira, a za to nisu dostatni samo ekonomija, rat i ideologija od liberalne fikcije ljudskih prava do ekstremnih zahtjeva za integracijom Drugih u nacionalno-kulturni korpus osvajača.

Sjetimo se da Schmitt u odredbi pravno-političkoga pojma moderne suverenosti jasno pokazuje da odluka kojom nastaje novi poredak djelovanja u svijetu nastaje ex nihilo. Sve državno-pravne teorije uglavnom zaobilaze taj trenutak misterija nastanka političkoga, tu začudnu kontingentnu narav preobrazbe ljudskog društvenoga okružja i njegova svijeta života. Odluka u procesu odlučivanja, dakle, proizlazi iz singularnoga događaja koji može imati manihejski karakter logike ili-ili, a tako u stvarnosti i funkcionira političko nadmetanje između država u svjetskoj povijesti. Pritom je od presudne važnosti pitanje, metafizički govoreći, subjekta odlučivanja i izvršenja odluke. Ako se suverenost na kraju epohe države i državnosti premješta i razmješta iz tzv. malog prostora teritorijalne uronjenosti u okvir etnički i kulturno određene nacije, kao što je to bilo u slučaju Francuske s njezinim mitom o državi koja stvara narod s univerzalnim značajkama civilne religije slobode i jednakosti, ili, pak, u slučaju Njemačke kada narod konstruira državu kao prostor homogene kulture s jasnim partikularnim značajkama (Rousseau vs. Fichte i Herder), onda je taj proces razmještanja onaj koji odlučuje o novome subjektu vladanja-i-upravljanja zemljom. To je, uistinu, taj novi nomos zemlje koji Schmitt prepoznaje kao pravi problem nastavka političkoga i politike drugim sredstvima u uvjetima postimperijalnoga Großrauma. U Političkoj teologiji ključne su postavke o biti političkoga i politike sljedeće: 
Za stvarnost pravnog života bitno je tko odlučuje. Uz pitanje o sadržajnoj točnosti stoji pitanje mjerodavnosti. U opreci između subjekta i sadržaja odluke, te u vlastitom značenju subjekta leži problem pravne forme. Ona ne posjeduje apriornu prazninu transcendentalne forme; jer ona nastaje upravo iz onoga što je pravno konkretno. Ona nema ni formu tehničke preciznosti; jer ta se odlikuje bitno predmetnim, neosobnim svrhovitim interesom. Naposljetku, ona nije ni forma estetskog oblikovanja, koje ne poznaje deciziju (Schmitt, 2019a, str. 40).

Tome usuprot, za Schmitta u novome nomosu zemlje, nakon povijesno-epohalnih prisvajanja i dijeljenja tla kao teritorija u Grka, s idejom rimskoga imperija i kršćanskoga svijeta res publica Christiana, preko Pax Britanica do jedinog svjetskoga hegemona kao što je Amerika, uvijek je riječ o proizvođenju zakona koji povezuje kapitalističku aproprijaciju vlasništva nad tlom s legitimnim subjektom izvršenja pravne odluke. A to je, naravno, istodobno i temeljni subjekt nove planetarno-globalne suverenosti. Govorimo o postimperijalnoj suverenosti iz jednostavnog razloga što tradicionalno određeni politički imperiji u 20. stoljeću - SAD, Rusija i Kina - iako i nadalje vode glavnu riječ o preustroju međunarodnih odnosa, ali sada je razlika u tome što u 21. stoljeću njihov ekonomski model osvajanja-prisvajanja Drugoga ima zajedničke značajke sprege neoliberalnoga i autokratsko-državnoga kapitalizma. Oligarhije su međusobno samo kulturno različite. Ista je logika korporativnoga umrežavanja i osvajanja prostora ekonomsko-političko-kulturalnoga utjecaja. Pritom se mijenja intenzitet koloniziranja i podvrgavanja projektiranih neprijatelja imperija novom načinu vladavine i upravljanja. Postimperijalna suverenost nije stoga stabilni poredak i prostor vladanja svijetom kao nomosom zemlje, već hibridno stanje u kojem prijatelj postaje neprijateljem i obratno ovisno o kontekstu rasporeda vanjsko-političkih ciljeva.

Želimo li izvesti konzekvencije ovog načina mišljenja, onda moramo imati u vidu da je čitav problem s prelaskom pojma vladanja u upravljanje i upravljaštvo svijetom, onaj nomos zemlje koji označavamo pojmom neoliberalizma kao sprege ekonomsko-političko-kulturalnoga imperijalizma. Time postaje jasno zašto je prepiska Schmitta s Kojèveom sredinom 1950-ih godina jedinstveni dokument traganja za novim političkim mišljenjem nakon kraja Hegelove spekulativne dijalektike, razdoblja totalitarizama i ulaska u doba koje možemo različito znamenovati, primjerice, post-političkim krajem ideologija kao u sociologijskome određenju Daniela Bella 1960-ih godina, ili krajem povijesti kao u politologijskome određenju Francisa Fukuyame 1990-ih godina. No, jedno je svemu tome zajedničko. Suverenost sada postaje vladanje kao upravljanje zemljom na temelju novoga nomosa koji se ne zasniva u transcendentalnoj fikciji IUS PUBLICUM EUROPAEUM. Umjesto toga, kako Schmitt to izvodi u zadnjem poglavlju Nomosa zemlje u kojem razmatra razlog zašto ideja svijeta kao kozmopolisa iz prosvjetiteljsko-metafizičkoga sklopa Kan- 
tova univerzalizma više ne može biti mjerodavnim filozofijsko-političkim uvjetom mogućnosti sveze i odnosa poretka i uprostorenja (Ordnung und Ortung), na djelu je odlučivanje o načinu razmještanja teritorija u smislu njegove nove razdiobe i osvajanja. Novo shvaćanje logike poretka i uprostorenja postaje odlučujuće za imperijalnu politiku proširenja tzv. nacionalne sigurnosti. Ono podaruje geopolitici značenje globalnoga decizionizma (Moore, 2020). Obrat je u tome što sada uprostorenje poretku određuje ontologijske granice vladanja. Upravljanje više nije izvršenje Zakona kao vladanja, već autonomno djelovanje implozije prostora kao teritorija koji se dijeli, raspoređuje i preobražava u logiku metamorfnoga kapitala. U 21. stoljeću vidimo dosege ove geopolitičke transformacije kao što je to rusko neoimperijalno posezanje za teritorijem Arktika u sukobu s Amerikom. Razlog želje za vladanjem kao upravljanjem Sjeverom Zemlje leži u tome što se globalnim zagrijavanjem otapa led i tako stvara mogućnost da Rusija u svojem presezanju za međunarodnim područjem mora ubrzano stekne više od $50 \%$ teritorija na koje polaže pravo.

Schmitt je razabrao da su stare institucije zaštite nacionalne suverenosti u doba postkolonijalnih ratova za državnost u trećem svijetu, poput UN-a, primjerice, izgubile vjerodostojnost zbog toga što nisu više bile učinkovite u sprečavanju sukoba tradicionalnim sredstvima pregovora između zaraćenih strana nastojanjem priznanja zatečene situacije na terenu. Ovi su ratovi, usto, doveli u pitanje bit modernoga imperijalizma - kolonijalizam. Jedino pravno-političko pitanje o ovoj novoj suverenosti bez naroda kao izvora vladanja jest pitanje legitimnosti odlučivanja o prisvajanju i osvajanju prostora Zemlje. Ako to više ne leži u teologijskoj nadležnosti Boga i Crkve, kao transcendentalnoga jamstva svake moguće kolonizacije "plemenitih divljaka" kao u doba Kolumba s ulogom katoličke Crkve i njezine nasilne evangelizacije svijeta, onda se umjesto svetosti pojavljuje svjetovna pluralnost politike s idejama slobode, jednakosti i pravednosti. No, nije to više horizont civilizacije univerzalnosti Francuske revolucije, već moment uspostavljanja nove civilne religije koja s Američkom revolucijom ima u vidu prosvjetiteljstvo i pitanje rješavanja ropstva u vlastitome dvorištu. Stoga, umjesto vjere u kršćanskoga Boga, nova rekonkvista usmjerava pozornost u 21. stoljeću na borbu za ljudska prava kao ideologijsko sredstvo novoga kolonijalizma i imperijalizma. U borbi protiv terora islamistički nadahnutih "kriminalnih država" sve je dopušteno, pod uvjetom da je legitimnost okupacije suverene države poput Afganistana i Iraka, primjerice, određena težnjom za oslobađanjem zemlje od neprijatelja i proglašenjem permanentnog izvanrednoga stanja. Taj vrli, novi nomos zemlje, međutim, ne može ostati u globalnome "prirodnome stanju" jer bi tek tada bila realizirana hobsovska distopija bellum omnium contra omnes. Mora nešto ostati postulatom, ali ne u kantovskome smislu normativne fikcije. To što preostaje od metafizike kao teologije u trenucima prazne uzvišenosti ratova i sukoba u Großraumu može se opisati kao sveza nomosa i lexa međunarodnoga prava polazeći od stajališta koje obuhvaća pojam singularne 
$i$ kontingentne suverenosti. Ona se ne može izvesti apriorno, već samo iz pojedinačnoga čina. Tako postaje izvjesno da u sebi nosi onu bestemeljnu slobodu odluke koja zacijelo ne može parirati američkome neoliberalizmu povratkom u stanje prije novoga nomosa zemlje. Nije otuda slučajno zašto Schmitt završava tekst ovog spisa s analizom tzv. pravednoga rata (Schmitt, 1974, str. 288-299).

Iako je, naravno, i u tom pojmu prisutan odjek kršćansko-humanitarnoga shvaćanja rata kao svetog sredstva za ozbiljenje univerzalne pravednosti koja povezuje ljudsko i božansko, njegova uporaba ima izrazito sekularne značajke. Još je znakovitije da se promišljanje ovoga pojma u kritičkome dijalogu i sa Schmittom kao adresatom pojavljuje učestalo u 21. stoljeću u američkoj političkoj misli (Walzer, 2015). Inflacija pojmovne uporabe pravde i pravednosti povezuje pravni diskurs međunarodnih odnosa u doba koje više nema, rekao bi Schmitt, uspostavljen vrijednosni sustav pravno-političke legitimnosti korištenja sile i nasilja u sukobima koji nemaju više karakter ratova između država, već ratnih sukoba između saveza država i mreže subjekata/aktera poput Islamske države, primjerice, al-Qaede itd. Što nam to svjedoči negoli da se međunarodno pravo raspalo kao sustav pravnih normi i naposljetku zakona. Jer zakon se ne poštuje upravo zbog toga što sudovi koji bi trebali rješavati takva prijeporna pitanja posezanja za tuđim teritorijem na zemlji, ulaženjem u jurisdikciju morskoga pojasa i slično, nemaju moć uvjeravanja silom u krajnjoj konzekvenciji. Zbog toga je uobičajeni postupak izravni dogovor ili sporazum između subjekata/aktera kao što su još uvijek to nacionalne države. Schmitt u uporabi temeljnoga pojma i izraza kao što je to nomos u grčkome značenju riječi ima u vidu glagol nemein, što znači nešto uzeti i prisvojiti, te osvojiti i tako osvojeno razdijeliti i podijeliti. Tri su osnovna značenja nomosa otuda prisvajanje, razdioba i proizvodnja (Schmitt, 1974, str. 36-48). U filozofijsko-političkome i pravnome smislu Schmitt etimologijski ulazi u fine razlike između nomosa i zakona, pokazujući uporabu riječi nomos kod Homera, sofista, Platona i Aristotela. Ono što je na stanovit način zajedničko različitim značenjima ove riječi jest jedinstvo onoga što smo već spominjali, a to je sveza-odnos poretka i uprostorenja. Imati vlasništvo nad zemljom u prostoru određenom krvlju i tlom, te morem kao vanjskom granicom, za Grke je značilo imati mogućnost vladanja nad sobom i drugima na način razdiobe onoga što nije tek zajedničko vlasništvo, nego ponajprije rezultat prisvajanja u smislu privatnoga vlasništva. No, nomos je ontologijska značajka vladanja nad zemljom kao tlom, dok su zakon i zakoni ontička pravno-politička legalnost poretka koji se nameće milom ili silom pripadnicima zajednice.

Političko značenje nomosa, dakle, proizlazi iz izvorne moći zaposjedanja i prisvajanja zemlje. Stoga je za Schmitta neupitno da se ovaj pojam pojavljuje gotovo obavijen mističnom tajnom Moći. Ona je dana čovjeku pod uvjetom da se njome služi svagda tako da razdjeljuje ono što je zajedničko, jer je bit privatnoga vlasništva nad zemljom u ozakonjenju izvornoga čina nasilnoga otimanja od prirode ili drugih 
ljudi upravo onog zajedničkoga izvora svekolika života - zemlje. Kad to imamo u vidu, nije teško zaključiti da Schmitt poseže za ovom riječju kao pojmom koji povezuje izvorno i suvremeno, arhajsko i današnje globalno kao uputstvo za uporabu u semantičkome i pragmatičkome smislu. To znači da je ovaj pojam konceptualni alat za razumijevanje vladanja kao upravljanja zemljom u doba posvemašnjeg raspada modernoga poretka nacija-država i njihova teritorijalnoga određenja prostora iz pojma suverenosti. Vladati ima izričito političko značenje, dok upravljati znači organizirati vlast i vladavinu u ekonomskom i kulturalnome smislu. Vidjeli smo, međutim, da Schmitt već u svojoj ranoj kritici liberalizma uočava kako se iza profanosti tehničko-ekonomskoga napretka suvremenih društava skriva bit liberalizma uopće. Što je taj ideologijsko-politički pojam značio za Schmitta odnosi se na zajednički nazivnik sekularizirane metafizike kapitalizma, ali i na mnogo više toga.

Sve što su mislioci liberalizma otvorili kao problem modernosti, od deizma u religiji do privatiziranja zajedničkoga dobra u politici i ekonomiji, smjeralo je onome što je Schmitt u govoru u Barceloni 1927. godine nepogrešivo opisao kao bit modernoga doba. Nemojmo zaboraviti da je njegova analiza modernosti kompleksna analiza procesa sekularizacije u Europi kao i nastanka znanstveno-tehničke racionalnosti novoga poretka kapitalizma. No, za razliku od Maxa Webera, u Schmittovim je uvidima proces birokratskoga racionaliziranja života u modernome društvu ono čudovišno što dovodi do pasiviziranja političkoga odlučivanja. U okružju kafkijanskoga labirinta vladavine Zakona bez temelja vlastite legitimnosti sam se život preobražava u mašineriju neljudskoga. Neutraliziranje moći onog političkoga i njegovo depolitiziranje čine uvjete mogućnosti suvremene post-politike neoliberalizma. Sažeto rečeno, kad se temeljna politička pitanja svode na pravne razmirice oko legitimnosti i legalnosti djelovanja, a suverenost pretvara u zastarjelu ideju vladavine bez stvarnoga subjekta Moći koji odlučuje u krajnjoj instanciji, tada se suočavamo s prelaskom u razdoblje novoga nomosa zemlje koji se može iskazati pojmom oligarhijske vladavine u poretku korporativizma suvremenoga svijeta. Odluka prethodi normi, događaj djelovanju, a Großraum postaje našom sudbinom u totalnoj borbi za prevlast nad tlom, morem, na nebu i na zemlji. Političko kao odluka i politika kao stanje u novome se nomosu zemlje pokazuju smislenom razlikom samo pod uvjetom stvaranja zajednice koja mora pomiriti kozmopolitizam i ideju nacije iz posve drukčijeg stajališta nego što je to bilo europocentrično shvaćanje suverenosti. U konačnici, Schmittova je politička ontologija decizionizma posljednji pokušaj očuvanja smisla događaja kao ljudske egzistencije u nabačaju nadolazeće zajednice s onu stranu svođenja na profit, interes i goli život homo oeconomicusa. ${ }^{7}$

${ }^{7}$ U knjizi Doba oligarhije pokazao sam razmjere ove kritike kapitalizma kako u Schmitta tako i u Kojèvea, te interpretacije Derride, Agambena, Mouffe i drugih zastupnika neomarksizma (Paić, 2017, str. 163-218 i 219-266). 


\section{Hannah Arendt i kritika Nomosa zemlje}

Mnogo je kritičkih pokušaja još i danas da se Schmittova temeljna knjiga geopolitike kao što je to Nomos zemlje jednostavno prekriži kao i njegova rana djela o političkome i političkoj teologiji s postavkom da je to samo sofisticirani plaidoyer za nastavak nacizma drugim sredstvima u uvjetima postnacionalne konfiguracije moći. Pa, zar nije, kao što je to pokazala i Hannah Arendt u Izvorima totalitarizma, ideja o III. Reichu uz ideologiju antisemitizma i politiku imperijalizma bila u nadilaženju epohe nacionalne državnosti i tradicionalnoga poretka europskog međunarodnoga prava (Arendt, 2015)? Drugim riječima, Schmitt je ovim svojim djelom samo potvrdio da se nikad nije razračunao s vlastitim tamnim sjenama nacizma. Jer, što bi bilo drugo žestoka kritika liberalizma negoli želja za održanjem na životu upravo onoga poretka što ga određuju protuprosvjetiteljstvo, militantni katolicizam, antisemitizam i vjernost idealima konzervativne revolucije (Wollin, 1992).

Nedavno pronađene marginalije što ih je Arendt brižljivo ispisivala na svojem primjerku Schmittova spisa potvrđuju, prema riječima autorice Anne Jurkevics, kako je posrijedi "fascinantan rezultat: Arendt je razvila koherentnu i odlučnu kritiku Schmittova narativa o geopolitici i međunarodnome pravu, ali to nije objavila. (...) Prema Arendt, Schmittova teorija u Nomosu zemlje... odgovara na pitanje-problem: gdje je izvor prava? u tlu. Njegovo fiksiranje na političko osvajanje tla jest nit vodilja koja se odmotava od svojih početnih filozofijskih razglabanja na čitavom putu kroz njegove historijske analize i kritiku američke hegemonije. Osvajanje je za Arendt zaključak Schmittova Nomosa te je iz njezine perspektive njegova geopolitička teorija iz temelja imperijalistička" (Jurkevics, 2016).

Već je iz ovoga bjelodano kako razlikovanje između Arendt i Schmitta polazi od toga što je za nju imperijalizam neprihvatljiv poredak vladavine i upravljanja svijetom te nužno zahtijeva kritičko razmatranje i pronalaženje mogućnosti nadilaženja njegovih izvora i posljedica. Naravno, u Izvorima totalitarizma i u drugim djelima pokazala je da je raspad onoga što Schmitt naziva međunarodnim pravom europskoga shvaćanja nacije-države u zbilji bio uvod u nastanak totalne države i nacističkoga totalitarizma. Najzlokobnija posljedica ovoga raspada, i tu je Arendt uistinu prva prikazala stanje stvari ogoljeno do srži, jest pitanje izbjeglištva, prognaništva i statusa ljudi bez državljanstva (stateless people). Autorica ovoga pregleda i analize njezinih bilješki uz čitanje Schmittova Nomosa zemlje precizno pokazuje koliko su postavke oboje političkih mislilaca, unatoč nepremostivim razlikama, usmjerene pokušaju odgonetanja zagonetke biti vladavine svijetom u doba globalne entropije. U tekstu marginalija vidimo i nešto doista iznimno važno za tumačenje Schmittova decizionizma. Primjedba bi se na stanovit način mogla smatrati paradoksalnom te možda čak i zajedljivom. Naime, Schmittov obrat od uvida u bit političkoga do njegove geopolitike za postimperijalnu suverenost Arendt objašnjava 
svojevrsnim razvitkom mišljenja politike polazeći od "pseudo-ontologijske metode", kako glasi primjedba na stranici 197. njezina primjerka Nomosa. Zar nisu oboje izvorni mislioci političkoga i politike nasuprot tradiciji političke filozofije koji su otvorili mogućnost razumijevanja novoga događaja iz perspektive egzistencijalnoga nabačaja slobode odluke i iz perspektive autonomije samog političkoga djelovanja u razlici spram znanosti, tehnologije, kulture i umjetnosti (Villa, 1995)? Zbog toga smatram neprimjerenom ovu primjedbu Hanne Arendt. Schmittovi su politički spisi sve drugo samo ne pseudo-ontologijska razglabanja. Bez uvjetno rečeno filozofijskoga promišljanja i jezično-analitičkoga rasklapanja temeljnih pojmova u historijskome razmatranju Schmitt ne bi nikad dospio do kristalne jasnoće svojih analiza pravno-političkih temelja modela vladavine od demokracije, diktature, pa do njegova 'izuma' kao što je to prijeporna i ujedno paradoksalno-aporetična teorija političke teologije. Štoviše, čak je i njegova postavka o politici kao sekulariziranju teologije toliko pregnantna da iz nje možemo očitati temeljni problem djelovanja u doba tehnosfere, kada političko traži neki uzvišeniji legitimitet od revolucije i ljudskih prava, od obećanja jedinstvene sreće u budućnosti čovječanstva do eshatologijskih ciljeva ozbiljenja nove Atene i Rima. Sa Schmittom smo u hobsijanskome realitetu politike par excellence, dok je u slučaju Arendt, unatoč njezinoj radikalnoj kritici imperijalizma i totalitarizma, pojam političkoga između Heideggerova događaja (Ereignis) i republikanske ideje vrijednosti ideala zajedničkoga dobra zajednice, što ovoj teoriji političkoga podaruje mistiku novoga i prizvuk tradicije sokratovske brige za dušu (Paić, 2015).

Mnogo je mjesta u marginalijama koje pokazuju suprotstavljene pozicije Schmitta i Arendt. Tako, primjerice, Arendt smatra njegove postavke o "herojskome dobu" u povijesti europske civilizacije kao pravno-političkoga poretka suverenosti nacionalnih država promašenom, jer je to tek "sjeme zla" koje će kulminirati s imperijalizmom u 19. stoljeću i kolonijalnim brutalnostima osvajača, a s totalitarizmom u 20. stoljeću sve će biti dovedeno do čudovišnih razmjera. Što li je onda za nju istinski nomos zemlje negoli složenija struktura odnosa od binarnoga koda prijatelj-neprijatelj kad je riječ o biti političkoga? To se posebno odnosi na pitanje Drugoga, odnosno manjinskih prava, osobito židovskoga naroda koji je istodobno u europskim nacijama-državama bio integriran kulturalno do najviših sfera duhovnosti u filozofiji, znanosti, umjetnosti, ali je sustavnim antisemitizmom podjarmljivan do granica nestanka u getima i prije apsolutnoga genocida u nacističkim logorima istrebljenja. Usto, Arendt razumije bit političkoga ne iz fascinacije državom i njezinim djelovanjem na pojedinca kako to čini Schmitt, već iz strukture pluralnosti ljudskoga djelovanja, njegove nesvodive slobodne usmjerenosti na dosezanje pravednosti i jednakosti u zajednici. Mogli bismo ovdje nizati postavke koje pokazuju da je nomos zemlje u postnacionalnoj konstelaciji za Schmitta pitanje poretka i uprostorenja osvajanja i prisvajanja zemlje u stalnim ratovima i sukobima s Dru- 
gim, jer je čovjek sve drugo negoli po prirodi dobar. S druge strane, Arendt u čitanju Nomosa rezolutno odbija svaku primisao na normalizaciju imperijalističkoga diskursa, premda i sama ne može naposljetku podariti zadovoljavajući odgovor na pitanje što nakon kraja europocentrizma, jer za razliku od Schmitta vidi u SAD-u nastavak imperijalizma i kolonijalizma drugim sredstvima. Schmittu je, pak, hegemonija i unilateralnost imperijalne uloge Amerike temeljni problem za ozbiljenje trajne koegzistencije drugih imperija u novome nomosu zemlje. Njezina pak kritika svakoga konsenzusa tzv. velikih sila u nametanju prividnoga mira u sukobima oko kolonijalnoga preotimanja prostora upravo je uzorno provedena: 1950-e i 1960-e godine bile su dokaz punog zamaha kako postkolonijalnih revolucija u trećem svijetu tako i uspona i sloma američke hegemonije. Ipak, nije to značilo i kraj imperijalizma, već tek razmještanje njegovih ciljeva uz pronalazak novih metoda osvajačkih politika.

Uglavnom, retorika osvajanja, okupacije, prisvajanja zemlje za Arendt je zoran dokaz kako je Schmittova geopolitika neprihvatljiv teoretski priručnik za novo koloniziranje nakon što je razdoblje ideologija postalo nepovratna prošlost, te su na njihovo mjesto stupile "pseudo-ontologijske metode" razvitka strategije nove razdiobe prostora u globalnim okvirima. Ako se uopće mogu iz navedenih marginalija izvesti neke pretpostavke za geopolitičko mišljenje Hanne Arendt u razlici spram Schmitta, onda su one ponajprije, kako je to pokazala Jurkevics, u razumijevanju nomosa zemlje koje ne proizlazi iz tla kao izvora prava. Za Arendt je pravo ono što ne nastaje iz nasilja osvajanja i prisvajanja, već iz intersubjektivnoga procesa djelovanja i proizvođenja novoga u javnome životu. Pravo je, dakle, ono što ne opravdava nasilje. Ono proizlazi iz ljudske težnje za ozbiljenjem slobode, jednakosti, pravednosti i prijateljstva ili solidarnosti u zajednici. Ovo kao da je bilo odlučujuće za Derridinu kritiku Schmittove teorije političkoga, kada je u kasnoj fazi svojega mišljenja uistinu dekonstruirao ono što pripada ovoj intersubjektivnosti, te je za nadolazeću zajednicu svojevrsnoga mesijanstva bez Mesije uzeo pojam prijateljstva (philia) s kojim zajednički bitak u onome političkome osvjetljava prostor ljudske povijesne egzistencije (Derrida, 1994).

\section{Zaključak}

Gotovo je nemoguće političkome mišljenju u doba postimperijalne suverenosti pojmovno-kategorijalno odrediti stabilni poredak snaga, interesa i strasti u vođenju zajedničkoga života na zemlji. Političko se ne može znanstveno-tehnički misliti kao ono računajuće i aplikativno, iako u mnogim aspektima pragmatika znanja i ovdje rukovodi ljudskim akcijama. I samome Schmittu bilo je od samoga početka više negoli bjelodano što bitno nedostaje njegovu decizionizmu. Riječ je o mogućnostima da se neproračunljivi događaj odluke o iznimnome ili izvanrednome stanju ne pro- 
longira u lošu beskonačnost, kao što se na stanovit način zbiva u 21. stoljeću kad smo ostali bez iluzije o veličajnoj europskoj suverenosti iza koje je mračna tajna kolonijalizma i imperijalizma ono što kroz misiju Amerike od kraja II. svjetskoga rata prožima i određuje svaki govor o slobodi i ljudskim pravima. Usto, glavnim političkim misliocima suvremenosti, a to su svojevrsni moderni klasici poput Schmitta i Arendt, bilo je razvidno da političko i politika ne mogu biti pozitivno određeni upravo zbog toga što bi njihovo znanstveno susprezanje značilo i redukciju čovjeka na animal rationale, kako je to postavio Aristotel u svojoj Politici. A upravo je ova odredba najspornije mjesto uopće za svaku buduću političku ontologiju i antropologiju. Zoon politikón sve je drugo negoli tek živo biće koje govorom iskazuje svoje umne mogućnosti vođenja i upravljanja životom zajednice. Ni anđeo ni Mefisto, ali između ovih figura protječe život čovjeka kao nesvodljivo političkoga bića.

Bez strasti i gorljive želje za sudjelovanjem u stvaranju općeg dobra zajednice, misaono ili djelatno, ne postoji ono ljudsko u političkome događaju koji svagda ima karakter kontingencije i novoga bez uzora u povijesnoj prošlosti. Schmitt je pojmom političke teologije otvorio pitanje o onome što stoji iza ove borbene i konfliktne igre oko priznanja u svijetu država i carstava. No, ni Bog ni tehnologije upravljanja svijetom kao racionalnim poretkom ljudskoga života ne mogu biti posljednja rješenja spasonosnoga događaja. Tko misli političko i politiku u doba postimperijalne suverenosti, mora odrješito prijeći s onu stranu svake normativne iluzije metafizike kakva je određivala naš povijesno-epohalni razvitak od Homera do nomosa zemlje bez prijatelja i neprijatelja, zemlje kao dehumanizirane pustinje kroz koju prolazimo tragajući za novom zemljom, svjesni da smo smrtni i da o našim odlukama ovisi čak i život ne samo čovjeka već i svekolikih drugih bića. No, što nosi i uvjetuje ovu strast za djelovanjem s onu stranu svake opsjednutosti razumom i umnim postulatima života čovjeka ako ne bestemeljnost njegove slobode, tog istinskoga arché i eschatona događanja povijesti? Nije slučajno Hannah Arendt u ogledu Što je sloboda? gotovo u kamen uklesala i ove riječi:

Sloboda... nije samo jedna od mnogih pojava i problema svijeta politike, strogo uzevši, kao pravda, ili moć, ili jednakost; sloboda koja samo rijetko - u vremenima krize ili revolucije - postaje izravan cilj političkoga djelovanja, zapravo je razlog što ljudi uopće žive zajedno u političkim organizacijama. Bez toga, politički bi život kao takav bio besmislen (Arendt, 1961, str. 146).

Vladanje i upravljanje zemljom na ishodu njezine povijesno-epohalne sudbine bez slobode kao da više nije dostojno biti čovjeka. Može li se tome usuprot pronaći novi put do otvorenosti svijeta s onu stranu stvaralačko-razaralačke biti političkoga i politike? 


\section{LITERATURA}

Agamben, G. (2000). Means without End: Notes on Politics. University of Minnesota Press. Minneapolis i London.

Agamben, G. (2005). State of Exception. Chicago University Press. Chicago.

Alliez, É. i Lazzarato, M. (2016). Wars and Capital. Semiotext(e), The MIT Press. Cambridge, MA i London.

Arendt, H. (1961). What is Freedom? U: Between Past and Future: Six Exercises of Political Thought. The Viking Press. New York.

Arendt, H. (2015). Izvori totalitarizma. Disput. Zagreb.

Critchley, S. (2012). The Faith of the Faithless. The Experiments in Political Theology. Verso. London i New York.

Deleuze, G. i Guattari, F. (2017). Što je filozofija? Sandorf i Mizantrop. Zagreb.

Derrida, J. (1994). Politiques de l'amitié. Éditions Galilée. Pariz.

Derrida, J. (2005). Rogues. Two Essays on Reason. Stanford University Press. Stanford.

De Vries, E. (2001). Discussion: Alexandre Kojève - Carl Schmitt Correspondence and Alexandre Kojève's "Colonialism from a European Perspective". Interpretation, 29 (1): $91-130$.

Heidegger, M. (2018). Sein und Zeit. GA, sv. 2. 2. izd. V. Klostermann. Frankfurt/M.

Jurkevics, A. (2016). Hannah Arendt liest Carl Schmitts Der Nomos der Erde: Ein Dialog über Gesetz und Geopolitik anhand ihrere Marginalien, 8. travnja. https://www. HannahArendt.net. 1. izd., sv. 8. Marginalije se mogu pronaći na web-stranici http:// www.bard.edu/arnddtcollection/

Lemke, T. (2019). Foucault's Analysis of Modern Governmentality. A Critique of Political Reason. Verso. London i New York.

Lévinas, E. (2009). Totalité et infini: essai sur l'extériorité. Les Livres de Poche. Pariz.

Löwith, K. (1984). Der okkasionelle Dezisionismus von Carl Schmitt. u: Heidegger Denker in dürftiger Zeit. Sämtliche Werke, sv. 8. J.B. Metzler. Stuttgart, str. 32-71.

Luhmann, N. (2002). Die Politik der Gesellschaft. Suhrkamp. Frankfurt/M.

McCormick, J. P. (1997). Carl Schmitt's Critique of Liberalism. Cambridge University Press. Cambridge i New York.

Meierhenrich, J. i Simons, O. (ur.). (2017). The Oxford Handbook of Carl Schmitt. Oxford University Press. Oxford.

Moore, T. (2020). On the theopolitics of sovereignty: Carl Schmitt and the theopolitics of global orders. Cambridge University Press. Review of International Studies, 46 (5): 691-712. DOI: https://doi.org/10.1017/S026021052000005. https://www. cambridge.org/core/journals/review-of-international-studies/article/abs/on-the-theopolitics-of-sovereignty-carl-schmitt-and-the-theopolitics-of-global orders/A63E20201A2FAA455F60B88E10D63ECE (2. ožujka). 
Ottmann, H. (2010). Decizionistički modeli politike. Politička misao, 47 (1): 129-141.

Paić, Ž. (2013). Sloboda bez moći. Politika u mreži entropije. Bijeli val. Zagreb.

Paić, Ž. (2015). Misterij novoga početka: Hannah Arendt i političko u suvremeno doba.

U: Totalitarizam? Meandarmedia. Zagreb. str. 75-134.

Paić, Ž. (2017). Doba oligarhije. Od informacijske ekonomije do politike događaja. Litteris. Zagreb.

Paić, Ž. (2018). Tehnosfera, sv. I. Žrtvovanje i dosada: Životinja-Čovjek-Stroj. Sandorf i Mizantrop. Zagreb.

Paić, Ž. (2019). Tehnosfera, sv. IV. Sklop i petlja. Što je preostalo od arhitekture? Sandorf i Mizantrop. Zagreb.

Paić, Ž. (2020). Neoliberalism, Oligarchy and Politics of the Event. At the Edge of Chaos. Cambridge Scholars Publishing. Newcastle upon Tyne.

Rodin, D. (2012). Poraz prosvjetiteljstva. Naklada Breza. Zagreb.

Schmitt, C. (1932). Der Begriff des Politischen, Mit einer Rede über das Zeitalter der Neutralisierungen und Entpolitisierungen. Duncker und Humblot. München i Leipzig.

Schmitt, C. (1974). Der Nomos der Erde im Völkerrecht des Jus Publicum Europaeum. 2. izd. Duncker und Humblot. Berlin.

Schmitt, C. (2018). Der Leviathan in der Staatslehre des Thomas Hobbes. Sinn und Fehlschlag eines politischen Symbols. Klett-Cotta. Stuttgart.

Schmitt, C. (2019a). Politička teologija - Politička teologija II. Naklada Breza. Zagreb.

Schmitt, C. (2019b). Politička romantika. Naklada Breza. Zagreb.

Stiegler, B. (2015). Von der Biopolitik zur Psychomacht. Die Logik der Sorge I.2. 2. izd. Suhrkamp. Frankfurt/M.

Vesting, T. (1992). Erosionen staatlicher Herrschaft. Zum Begriff des Politischen bei Carl Schmitt. Aör, 117: 4-45.

Villa, D. (1995). Arendt and Heidegger. The Fate of the Political. Princeton University Press. Princeton.

Walzer, M. (2015). Just and Unjust Wars. A Moral Argument with Historical Illustrations. Basic Books. New York.

Wollin, R. (1992). Carl Schmitt: The Conservative Revolutionary Habitus and the Aesthetics of Horror. Political Theory, 20 (3): 424-447.

Žižek, S. (1999). Carl Schmitt in the age of post-politics. U: Mouffe, C. (ur.). The Challenge of Carl Schmitt. Verso. London i New York. str. 18-37. 


\title{
Žarko Paić \\ WHAT IS POST-IMPERIAL SOVEREIGNTY? \\ ABOUT THE NOMOS OF THE EARTH - CARL SCHMITT AND CRITICAL READING BY HANNAH ARENDT
}

\begin{abstract}
Summary
In the article, the author analyzes Carl Schmitt's book The Nomos of the Earth by asking how, after the nation-state era and the collapse of European imperialism, which was also the starting point of Hannah Arendt's Origins of Totalitarianism, the conditions for the possibility of political action are established, since this action no longer has for its existential space the idea of rootedness in the nation as a state with mechanisms for the protection of sovereignty with the help of legislative, executive and judicial power enshrined in the constitution. Power is not just a state-social logic of managing a fixed space and a limited nation-state territory, as was customary from the 18th century in Europe until the end of World War I. Schmitt in the second period of his philosophical and legal thought, formally and substantively after the end of World War II, saw the political and politics as the universal geopolitics of the "large space" (Großraum). The existential-decisionist turn proves to be the main reason why Schmitt's notion of the political cannot be declared a justification for any dictatorship or totalitarianism. The decision rests on an empty centre of freedom, not a power. The Nomos of the Earth in the post-national constellation for Schmitt thus becomes a matter of order and spatializing in the conquest and appropriation of land in constant wars and conflicts with the Other, because man is anything but good by nature. A critique of this position in the marginals of Hannah Arendt alongside Schmitt's book The Nomos of the Earth opens up the possibility of discussing the limits of neo-imperialism and the new legal-political constitution of the world after World War II. The author claims that the result of this aporetic and paradoxical situation in the 21 st century lies precisely in the so-called post-imperial sovereignty as a continuation of Schmitt's postulate of the state of exception on a global-planetary level. The political precedes politics as the new nomos of the Earth requires a turn in the notion of the relationship of freedom and power.
\end{abstract}

Keywords: Post-imperial Sovereignty, Schmitt, Arendt, The Nomos of the Earth, Political Theology, Neo-imperialism

Žarko Paić, filozof, sociolog i politolog, profesor estetike, teorije znanosti i novih medija na Tekstilno-tehnološkom fakultetu Sveučilišta u Zagrebu.

Kontakt: Žarko Paić, Tekstilno-tehnološki fakultet, Prilaz baruna Filipovića 28a, 10000 Zagreb. E-mail: zarko.paic@ttf.unizg.hr 